\title{
Dependence on $\mathrm{O}_{2}^{-}$Generation by Xanthine Oxidase of Pathogenesis of Influenza Virus Infection in Mice
}

\author{
Takaaki Akaike, ${ }^{\star \ddagger}$ Masayuki Ando, ${ }^{\ddagger}$ Tatsuya Oda, ${ }^{*}$ Toshinori Doi, ${ }^{\star \ddagger}$ Sumiko ljiri, ${ }^{\star}$ Shukuro Araki, ${ }^{\star}$ and Hiroshi Maeda* \\ ${ }^{*}$ Departments of Microbiology and ${ }^{\ddagger}$ First Department of Internal Medicine, Kumamoto University \\ School of Medicine, Kumamoto 860, Japan
}

\begin{abstract}
We evaluated various biochemical parameters in influenza virus-infected mice and focused on adenosine catabolism in the supernatant of bronchoalveolar lavage fluid (s-BALF), lung tissue, and serum (plasma). The activities of adenosine deaminase (ADA) and xanthine oxidase (XO), which generates $\mathrm{O}_{2}^{-}$, were elevated in the s-BALF, lung tissue homogenate, and serum (plasma). The elevations were most remarkable in s-BALF and in lung tissue: We found a 170-fold increase in ADA activity and a 400 -fold increase in XO activity as measured per volume of alveolar lavage fluid. The ratio of activity of XO to activity of xanthine dehydrogenase in S-BALF increased from $0.15 \pm 0.05$ (control; no infection) to $1.06 \pm 0.13$ on day 6 after viral infection. Increased levels of various adenosine catabolites (i.e., inosine, hypoxanthine, xanthine, and uric acid) in serum and s-BALF were confirmed. We also identified $\mathrm{O}_{2}^{-}$generation from XO in s-BALF obtained on days 6 and 8 after infection, and the generation of $\mathrm{O}_{2}^{-}$was enhanced remarkably in the presence of adenosine. Lastly, treatment with allopurinol (an inhibitor of $\mathrm{XO}$ ) and with chemically modified superoxide dismutase (a scavenger of $\mathrm{O}_{2}^{-}$) improved the survival rate of influenza virus-infected mice. These results indicate that generation of oxygen-free radicals by XO, coupled with catabolic supply of hypoxanthine from adenosine catabolism, is a pathogenic principle in influenza virus infection in mice and that a therapeutic approach by elimination of oxygen radicals thus seems possible. (J. Clin. Invest. 1990. 85:739-745.) viral pathogenesis $\bullet$ free radicals $\bullet$ xanthine oxidase $\cdot$ SOD
\end{abstract}

\section{Introduction}

Certain evidence suggests that the lethal effect of influenza virus infection in mice is determined by immunopathological consequences of the host rather than the direct cytopathic effect of viral replication (1-3). There is no report, except for our recent preliminary one (4), on the molecular mechanism of pathological damage in the lung of influenza virus-infected hosts. On the other hand, many workers in the field of inflammation have expressed a growing awareness in recent years of

Parts of this work were presented at the International Conference on Medical, Biochemical, and Chemical Aspects of Free Radicals, 9-13 April, 1988, in Kyoto, Japan.

Address reprint requests to Dr. H. Maeda, Department of Microbiology, Kumamoto University School of Medicine, Kumamoto 860 Japan.

Received for publication 11 July 1989.

J. Clin. Invest.

(C) The American Society for Clinical Investigation, Inc.

0021-9738/90/03/0739/07 \$2.00

Volume 85, March 1990, 739-745 oxygen-derived free radicals as a cause of tissue injuries. Particular attention has been focused on the pivotal deleterious effect of free radicals in the pathogenesis of adult respiratory distress syndrome (ARDS) ${ }^{1}(5,6)$, pulmonary emphysema (7), hyperoxic pulmonary injuries (8), and other inflammatory diseases $(9,10)$

Many recent reports implicate oxygen-free radicals as a mediator of ischemia-reperfusion injury, in which xanthine oxidase (XO), which generates toxic $\mathrm{O}_{2}^{-}$as a metabolite, could be responsible for tissue injuries in biological systems $(11,12)$. In this pathological system, enhancement of cellular adenosine catabolism (after ATP degradation) yields high levels of hypoxanthine and xanthine, resulting coincidentally in effective supply of a substrate for $\mathrm{XO}$. On the other hand, conversion of xanthine dehydrogenase (XD) to XO is also accelerated. Thus, these two simultaneous processes seem to accelerate the generation of free radical and remarkably elevated production of $\mathrm{O}_{2}^{-}$ becomes possible (Fig. 1) (11). Furthermore, there is now evidence that the level of XO in plasma is elevated in ARDS (13) and that $\mathrm{XO}$ mediates lung injury by neutrophil-elastase and hyperoxia (14).

These suggestive data prompted us to hypothesize that $\mathrm{XO}$ causes $\mathrm{O}_{2}^{-}$generation, which could produce highly toxic $\cdot \mathrm{OH}$ $(15,16)$ in the pathogenesis of influenza virus infection (4). We therefore investigated the pathogenic role of $\mathrm{O}_{2}^{-}$induced by a cascade of adenosine catabolism in influenza virus-infected mice. The present results show that $\mathrm{O}_{2}^{-}$is generated because of an elevated level of both XO and its substrate, as a result of increased levels of adenosine catabolites such as hypoxanthine and xanthine. Further, we show that removal of $\mathrm{O}_{2}^{-}$from the system has therapeutic consequences in this viral infection. This is the first detailed report of the pathogenic role of XO in influenza virus infection in animals.

\section{Methods}

Animals. SPF grade male ddY mice, 5-6 wk old, were obtained from Japan SLC (Shizuoka, Japan).

Substances. Bovine Cu, Zn SOD, pterine(2-amino-4-hydroxypteridine), and ferricytochrome $c$ were purchased from Sigma Chemical Co., St. Louis, MO. Divinyl ether-maleic acid copolymer (pyran copolymer) was a gift from Dr. T. Hirano, Institute of Textile and Polymer, Tsukuba, Japan. SOD and pyran copolymer anhydride were reacted in an aqueous milieu to yield a conjugate (pyran-SOD), as described previously (17). Isoxanthopterin(2-amino-4,7-pteridinediol) and allopurinol (4-hydroxypyrazolo[3,4-d]pyrimidine) were purchased from Aldrich Chemical Co., Milwaukee, WI. Leupeptin was a kind gift from

1. Abbreviations used in this paper: ADA, adenosine deaminase; ARDS, adult respiratory distress syndrome; BALF, bronchoalveolar lavage fluid; LD, lethal dose; pyran-SOD, pyran polymer-conjugated SOD; s-BALF, supernatant of BALF; XD, xanthine dehydrogenase; $\mathrm{XO}$, xanthine oxidase. 


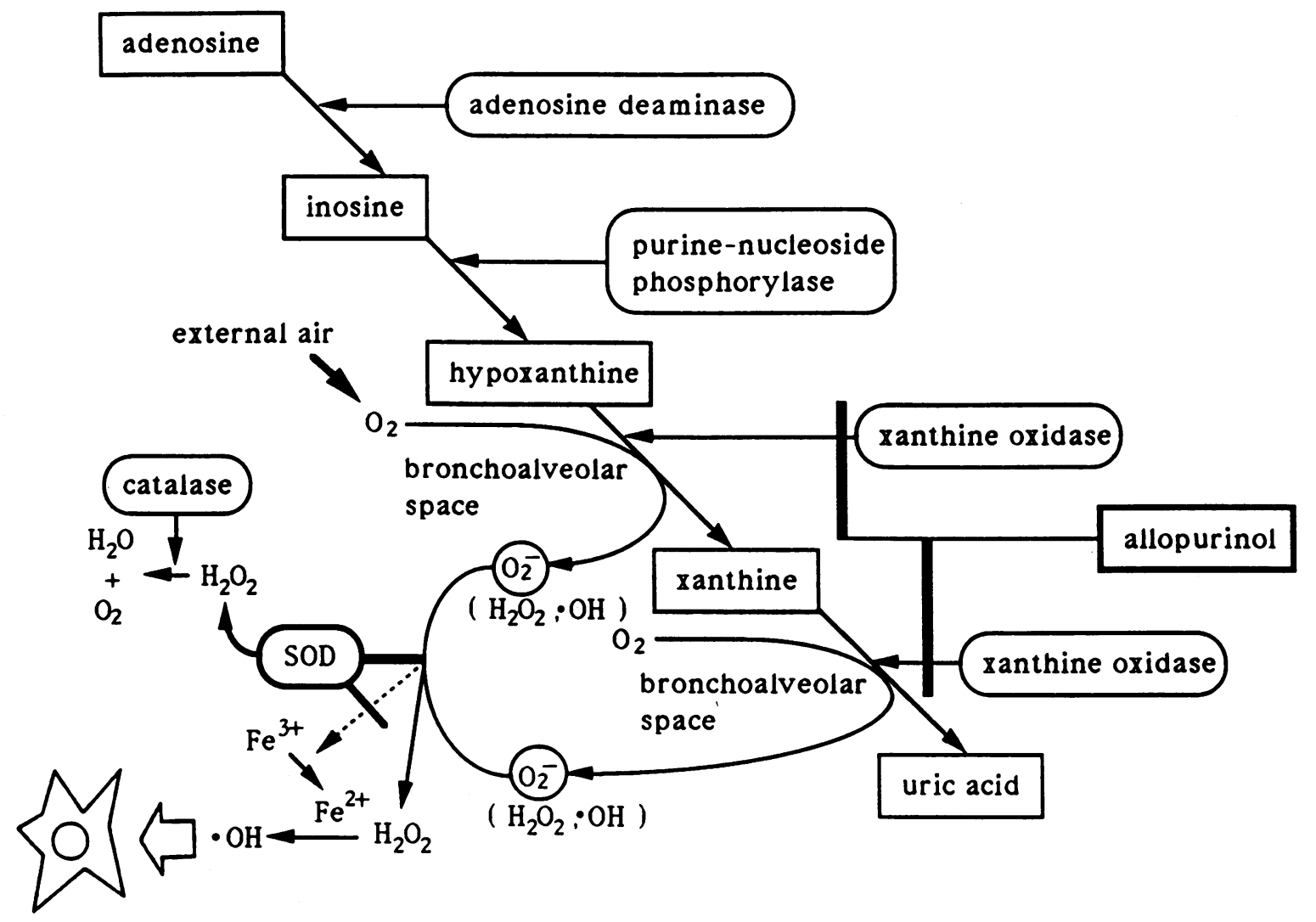

cell and tissue injury

Figure 1. Adenosine catabolism and generation of oxygen-free radicals in influenza virus-infected lung. XO, which is the final enzyme in purine catabolism, transfers electrons to molecular oxygen to form superoxide anion $\left(\mathrm{O}_{2}^{-}\right) . \mathrm{O}_{2}^{-}$can be converted into highly toxic hydroxyl radicals by the iron-catalyzed Haber-Weiss reaction (16). Square boxes indicate purine metabolites. Enzymes involved are shown in rounded boxes. Allopurinol inhibits XO.

the late Dr. H. Umezawa (Institute for Microbial Chemistry, Tokyo, Japan). $\left[2,8-{ }^{3} \mathrm{H}\right]$ Adenosine was purchased from ICN Radiochemicals, Irvine, CA. DTT was obtained from Boehringer Mannheim GmbH, Mannheim, FRG. Amino PMSF and all other chemicals were purchased from Wako Pure Chemical Industry Co., Ltd, Osaka, Japan.

Virus and virus assay. Influenza virus $\mathrm{A} / \mathrm{Kumamoto} / \mathrm{Y}_{5} /$ $67\left(\mathrm{H}_{2} \mathrm{~N}_{2}\right)$, adapted to the mouse, was used throughout the experiments. Virus yield in the lung was quantitated by the plaque-forming assay with Madin-Darby canine kidney cells cultured with DME. Virus-inoculated cells were overlayed with DME agar containing trypsin as described in our recent report (18).

Scoring of the pathological pneumonic process in the lung. After the perfusion of mice lungs via the pulmonary artery with $0.01 \mathrm{M}$ phosphate-buffered $0.15 \mathrm{M} \mathrm{NaCl}$ (PBS; $\mathrm{pH}$ 7.4) to remove trace amounts of red blood cells, the extent of consolidation was scored according to the method of Ginsberg and Horsfall (19), with a slight modification.

Production of influenza virus infection in mice. Experimental influenza virus pneumonia was produced in mice as described in our previous report (18). Briefly, mice were inoculated by inhalation of a viral suspension at twice the $50 \%$ lethal dose $\left(2 \times \mathrm{LD}_{50}\right)$ in the rotating nebulizer. After inoculation, various biochemical assays relevant to adenosine catabolism were undertaken using samples from mice as described below.

Preparation of samples: serum (plasma), bronchoalveolar lavage fluid (BALF), and lung tissue. Blood was obtained by cutting the carotid artery under light ether anesthesia, and plasma or serum was collected in the presence or absence of $2 \mathrm{mM}$ EDTA, $2 \mathrm{mM}$ amino PMSF, and $10 \mathrm{mM}$ DTT henceforth referred to as inhibitor cocktail. Bronchoalveolar lavages were performed as described previously (18).
Usually, lungs were lavaged twice with $1 \mathrm{ml}$ of ice-cold PBS containing 2 mM EDTA. For determination of XO activity, lungs were lavaged with PBS containing the inhibitor cocktail plus $0.5 \mu \mathrm{g} / \mathrm{ml}$ of leupeptin. The fluid from subsequent lavages was pooled and centrifuged at $400 \mathrm{~g}$ for $10 \mathrm{~min}$ at $4^{\circ} \mathrm{C}$ to remove cellular components. After mice were exsanguinated by cutting the abdominal aorta, the lungs were perfused with $2 \mathrm{ml}$ of ice-cold PBS containing the inhibitor cocktail and then were homogenized (Polytron homogenizer; Kinematica $\mathrm{GmbH}$, Lucerne, Switzerland) in $50 \mathrm{mM}$ potassium phosphate buffer pH 7.6 containing the inhibitor cocktail, plus $0.5 \mu \mathrm{g} / \mathrm{ml}$ of leupeptin at $4^{\circ} \mathrm{C}$. The homogenates were centrifuged at $10,000 \mathrm{~g}$ for $20 \mathrm{~min}$ at $4^{\circ} \mathrm{C}$, and the supernatants were filtered with a syringe filter of $0.45-\mu \mathrm{m}$ pore size (Corning Glass Works, Corning, NY).

Assay of adenosine deaminase (ADA) activity in serum and $B A L F$ We first assayed ADA activity radiochemically in serum and supernatant of BALF (s-BALF) of mice after virus inoculation as reported by Begleiter et al. (20), with a slight modification. Briefly, aliquots of s-BALF were incubated with a given volume of $6.4 \mu \mathrm{M}\left[{ }^{3} \mathrm{H}\right]$ adenosine (3.9 $\mathrm{Ci} / \mathrm{mmol} \mathrm{sp} \mathrm{act)} \mathrm{at} 37^{\circ} \mathrm{C}$ for various times. After the reaction was stopped with $0.15 \mathrm{M}$ perchloric acid, the conversion of adenosine to inosine, and then to hypoxanthine, xanthine, or uric acid (Fig. 1), was measured by quantitating radioactivity on thin-layer chromatography plates (Cellulose F; E. Merck, Darmstadt, FRG) after development with $n$-butanol/methanol/ $\mathrm{H}_{2} \mathrm{O} / \mathrm{NH}_{4} \mathrm{OH}$ (25\%) (60:20:20:1 [vol/vol]). ADA activity was expressed as milliunits per milliliter of serum or BALF. One unit corresponds to the reduction of $1 \mu \mathrm{mol}$ of adenosine/min.

Assay of activities of XO and XD in samples. Both XO and XD activities were assayed by a modification of the fluorometric method of 
Haining and Legan described below (21), which is more sensitive than the ultraviolet absorption spectrophotometric assay. 1-2.0 ml of the s-BALF centrifuged at $400 \mathrm{~g}$ to remove cells was dialyzed for $4 \mathrm{~h}$ against 5 liters of PBS at $4^{\circ} \mathrm{C}$ to remove the low molecular-weight compounds before determination of XO enzyme activity. In the case of plasma and lung homogenates, $0.5-1.0 \mathrm{ml}$ of plasma or of the supernatant of the lung homogenate was chromatographed on a Sephadex G-25 (Pharmacia Fine Chemicals, Uppsala, Sweden) column (1.5 $\times 35 \mathrm{~cm}$ ), which had been equilibrated with PBS at $4^{\circ} \mathrm{C}$. The column was eluted with PBS at $4^{\circ} \mathrm{C}$ (monitored by absorbance at $280 \mathrm{~nm}$ ), and proteins were separated from the second peak, which eluted later. Both samples were assayed for their XO activity using pterine as the substrate in a spectrofluorometer (model 650-40; Hitachi Ltd., Tokyo, Japan) with excitation at $345 \mathrm{~nm}$ and emission at $390 \mathrm{~nm}$. The volume of the assay mixture was $1.0 \mathrm{ml}$ in PBS, which consisted of $9 \mu \mathrm{M}$ pterine and the putative enzyme from the samples. Reactions proceeded for $10-60 \mathrm{~min}$ at $37^{\circ} \mathrm{C}$. To measure both $\mathrm{XO}$ and $\mathrm{XD}$ activity, above reaction was carried out in the presence of $9 \mu \mathrm{M}$ methylene blue. To confirm the specificity of the activity, $20 \mu \mathrm{M}$ allopurinol was added to the above mixture and the reaction was carried out. The concentration of isoxanthopterin formed was calculated from the linear relationship between fluorescence intensity versus its concentration in 0-10 nmol of the product. Protein content in each sample was determined using bovine serum albumin as standard by the method of Lowry et al. (22).

Quantitation of catabolic purine metabolites. Catabolic adenosine metabolites were analyzed by HPLC (Asahipak GS-320; Asahi Chemical Co., Ltd., Tokyo, Japan) and by an isocratic elution with $0.01 \mathrm{M}$ PBS, pH 7.4. The eluate was monitored at $260 \mathrm{~nm}$. Each metabolite was identified by comparison of elution time with that of standard nucleoside derivatives or by enzymatic determination as substrate, and/or by analysis of the absorption spectrum. The amount of each purine derivative was calculated by measuring the peak area of the standard compounds (e.g., adenosine, inosine, hypoxanthine, xanthine, and uric acid). For the assay of catabolic metabolites in serum, samples were treated with trichloroacetic acid at $5 \%$ to remove proteins, then $\mathrm{pH}$ of the supernatant was adjusted to $\sim 7.8$ with $0.5 \mathrm{~N}$ $\mathrm{NaOH}$ before HPLC analysis. The elution times of inosine and uric acid was somewhat different under high salt content from those of standard solutions. In case of s-BALF, samples were filtered by Centricon (Amicon Corp., Danvers, MA) to remove macromolecular proteins and enzymes in the samples (cut off: 10,000 D), and the filtrates were used for the HPLC assay.

Conversion profile of adenosine in BALF. To examine the details of adenosine catabolism in the bronchoalveolar spaces (Fig. 1), we quantified each of the purine derivatives converted from adenosine after adding adenosine to the s-BALF in vitro. Usually $15.0 \mathrm{nmol}$ of adenosine was added to $1 \mathrm{ml}$ of s-BALF, and after various incubation times at $37^{\circ} \mathrm{C}$ the catabolic metabolites (inosine, hypoxanthine or xanthine, and uric acid) were quantitated by HPLC as described above. Since s-BALF contained endogenous adenosine metabolites, the same mixture of BALF without added adenosine was also incubated, and the amount of each metabolite determined was subtracted from the above values.

Measurement of $\mathrm{O}_{2}^{-}$generation in $\mathrm{BALF}$. For this assay, the bronchoalveolar lavages were performed twice with ice-cold PBS containing 2 mM EDTA. Cells and cell debris were removed by centrifugation at $400 \mathrm{~g}$ for $5 \mathrm{~min}$ at $4^{\circ} \mathrm{C}$ and were then filtered with syringe filters $(0.45 \mu \mathrm{m})$. The s-BALF was immediately subjected to spectroscopic assay for $\mathrm{O}_{2}^{-}$generation on the basis of SOD inhibitable reduction of ferricytochrome $c$ (23). Briefly, $0.1 \mathrm{ml}$ of supernatant was incubated with $80 \mu \mathrm{M}$ ferricytochrome $c$ in a total volume of $1.0 \mathrm{ml}$ of PBS in the presence or absence of SOD $(20 \mu \mathrm{g})$, adenosine $(22.5 \mu \mathrm{M})$, or allopurinol $(45 \mu \mathrm{M})$ for $30 \mathrm{~min}$ at $37^{\circ} \mathrm{C}$.

Treatment with allopurinol or SOD of virus-infected mice. To determine the pathogenic role of $\mathrm{O}_{2}^{-}$generation by $\mathrm{XO}$ in influenza virus-infected mice, we administered 1 or $2 \mathrm{mg}$ /day of allopurinol dissolved in PBS per mouse orally from day 4 to day 7 after virus inoculation at twice the $\mathrm{LD}_{50}$ dose. We expected that allopurinol, an inhibitor of $\mathrm{XO}$, would inhibit $\mathrm{O}_{2}^{-}$generation by $\mathrm{XO}$ induced in the virus-infected lung. In the separate experiments, $\operatorname{SOD}(1,000 \mathrm{U})$ or pyran-SOD $(200 \mathrm{U})$ was administered similarly but intravenously via the tail vein from day 5 to day 8 to remove $\mathrm{O}_{2}^{-}$. The daily survival rate of the mice was recorded until day 16 after infection.

Statistical analysis. All biochemical values are expressed as means \pm SE of three samples. The statistical differences in survival rate of mice treated with allopurinol or pyran-SOD after viral infection were determined by Fisher's exact probability test, with significance defined as $P<0.05$.

\section{Results}

Time course of viral replication, score of consolidation in the lung, and survival rate. As shown in Fig. 2, virus yield in the lung was maximal on day 4 , and then decreased markedly until day 8 after infection (or later) and became undetectable. On the other hand, pulmonary consolidation gradually increased after a long lag period and became maximal after day 8; at this point the lethal effect of infection became apparent and it increased rapidly thereafter. Thus, maximal viral yield does not parallel the maximal pathological effects, and an indirect mechanism may mediate lung tissue injuries.

$A D A$ and $X O$ activities in influenza virus-infected mice. ADA activity in serum and s-BALF increased markedly after viral infection (10-fold increase in serum and 170-fold increase in BALF) and became maximal on day 8 (Table I). This time course correlated with the consolidative process in the lung and mortality but not with virus replication (Fig. 2).

In parallel with consolidation, $\mathrm{XO}$ activity was also raised in each sample and was most remarkable in BALF (400-fold increase, as measured by enzyme activity per volume of lavage fluid). The activities of XO and ADA in s-BALF or the lung tissue expressed as activity per milligram protein also increased (Tables I and II). The XO/XD ratio (i.e., conversion of $\mathrm{XD} \rightarrow \mathrm{XO}$ ) increased significantly in parallel to the above results in s-BALF and in lung tissue (Fig. 3), but not in plasma. The highest $\mathrm{XO} / \mathrm{XD}$ ratio in s-BALF or in lung tissue was found on day 3 or day 6 , which was somewhat earlier than the increase of XO activity. These results indicated that the activity of both ADA and XO, which are important enzymes that are directly involved in adenosine catabolism (Fig. 1), was markedly enhanced by virus infection in mice. Furthermore, $\mathrm{XO}$ may be an inducible enzyme, and conversion of XD to $\mathrm{XO}$ was clearly taking place in the virus-infected lung.

Quantitation of catabolic metabolites of adenosine in virus-infected mice. We determined each step of adenosine catabolism after viral infection by quantitating inosine, hypo-

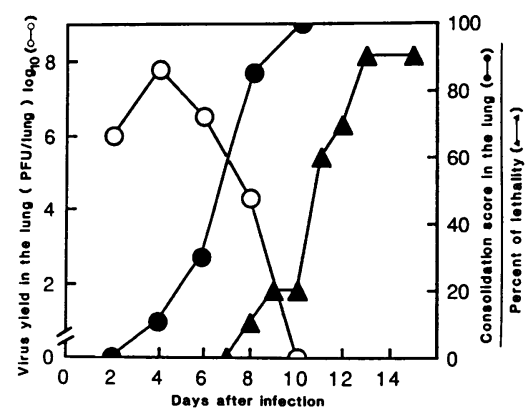

Figure 2. Time course of viral replication, score of consolidation in the lung, and survival rate of influenza virus-infected mice. Mice were inoculated by inhalation with the influenza virus $\mathrm{A} / \mathrm{Ku}$ mamoto/67 $\left(\mathrm{H}_{2} \mathrm{~N}_{2}\right)$ at twice the $\mathrm{LD}_{50}$ dose. Virus yield was quantitated by plaque-forming

assay, and the amount of consolidation was scored as described by Ginsberg and Horsfall (19). See text for details. 
Table I. ADA Activity in Serum and in s-BALF of Influenza Virus-infected Mice*

\begin{tabular}{ccc}
\hline & \multicolumn{2}{c}{ ADA activity } \\
\cline { 2 - 3 } $\begin{array}{c}\text { Day after } \\
\text { infection }\end{array}$ & In serum & In s-BALF \\
\hline 0 & $0.144 \pm 0.021^{\ddagger}$ & $0.002 \pm 0.000$ \\
& $(0.003 \pm 0.001)$ & $(0.012 \pm 0.000)$ \\
4 & $0.464 \pm 0.060$ & $0.054 \pm 0.001$ \\
& $(0.008 \pm 0.001)$ & $(0.148 \pm 0.001)$ \\
6 & $0.919 \pm 0.192$ & $0.149 \pm 0.001$ \\
& $(0.015 \pm 0.003)$ & $(0.135 \pm 0.001)$ \\
8 & $1.81 \pm 0.53$ & $0.353 \pm 0.132$ \\
& $(0.024 \pm 0.007)$ & $(0.146 \pm 0.054)$ \\
\end{tabular}

* ADA activity was assayed radiochemically as reported by Begleiter et al. (20), with a slight modification.

₹ Activity is expressed as milliunits per milliliter of serum or BALF. One unit corresponds to the diminution of $1 \mu \mathrm{mol}$ of adenosine/min. The corrected values (per milligram protein) are shown in parentheses. Values are shown as means \pm SE of three determinations.

xanthine, xanthine, and uric acid in serum and s-BALF of mice (Fig. 1). As shown in Table III, the level of the purine catabolites gradually increased in serum after viral infection, and the elevation was most remarkable on day 8 . The level of inosine and uric acid in S-BALF was also elevated most markedly on day 8. Hypoxanthine and xanthine in s-BALF, however, could not be detecfed in this system (i.e., values below 10 $\mathrm{ng} / \mathrm{ml}$ ). When we quantitated hypoxanthine in the s-BALF in the presence of allopurinol, to inhibit the conversion of hypoxanthine to uric acid in vitro, the content of hypoxanthine in the s-BALF on day 8 was $0.15 \pm 0.07 \mu \mathrm{g} / \mathrm{ml}$, while it was not detected in s-BALF on days 0 and 4 . Therefore, it is reasonable to assume that a rapid turnover was taking place under highly elevated XO activity in s-BALF and as a consequence hypo$x$ anthine and xanthine could not be detected. These results indicate that adenosine catabolism was enhanced by influenza virus infection in mice.

Table II. XO Activity in Plasma, s-BALF, and Lung Tissue*

\begin{tabular}{cccc}
\hline & \multicolumn{3}{c}{ XO activity (nmol isoxanthopterin/min) } \\
\cline { 2 - 4 } $\begin{array}{c}\text { Day after } \\
\text { infection }\end{array}$ & In plasma & In s-BALF & In lung tissue \\
\hline \multirow{2}{*}{0} & $0.229 \pm 0.004$ & $0.001 \pm 0.001$ & $0.758 \pm 0.179$ \\
& $(0.003 \pm 0.000)$ & $(0.001 \pm 0.000)$ & $(0.095 \pm 0.019)$ \\
3 & $0.262 \pm 0.007$ & $0.015 \pm 0.005$ & $1.043 \pm 0.091$ \\
& $(0.004 \pm 0.000)$ & $(0.018 \pm 0.006)$ & $(0.123 \pm 0.010)$ \\
6 & $0.240 \pm 0.025$ & $0.179 \pm 0.029$ & $15.7 \pm 3.94$ \\
& $(0.004 \pm 0.001)$ & $(0.041 \pm 0.007)$ & $(0.924 \pm 0.230)$ \\
8 & $0.766 \pm 0.090$ & $0.419 \pm 0.033$ & $22.4 \pm 1.38$ \\
& $(0.009 \pm 0.001)$ & $(0.044 \pm 0.003)$ & $(0.963 \pm 0.060)$
\end{tabular}

* XO activity was quantitated by the fluorometric method of Haining and Legan (21), with a slight modification.

‡ Activity is expressed as $\mathrm{nmol}$ isoxanthopterin/min per milliliter of plasma, lavaged fluid, or total lung homogenates. The corrected values expressed as per milligram protein are shown in parentheses. All these activities were completely inhibited by $20 \mu \mathrm{M}$ allopurinol. Values are shown as means $\pm \mathrm{SE}$ of three determinations.

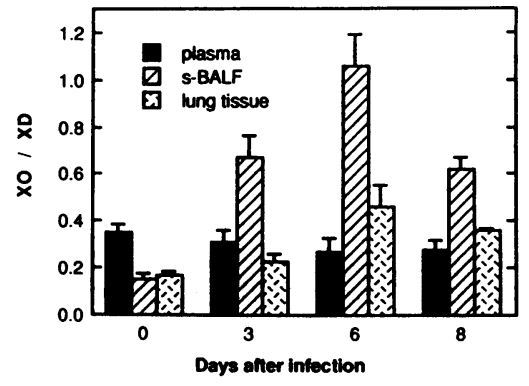

Figure 3. The $\mathrm{XO} / \mathrm{XD}$ ratio in plasma, $\mathrm{s}$ BALF, and lung tissue of virus-infected mice. $\mathrm{XO}$ and $\mathrm{XO}+\mathrm{XD}$ activities were determined fluorometrically in the absence or presence of 9 $\mu \mathrm{M}$ methylene blue according to the method of Haining and Legan (21). The ratio is calculated as XO activity/ $\mathrm{XD}$ activity. Data are means \pm SE, $n=3$.

Catabolism of adenosine in BALF. In s-BALF from the normal mouse lung, conversion of added adenosine to inosine was only marginal within $60 \mathrm{~min}$, and there was no production of uric acid. The rate of adenosine degradation starts to increase gradually in s-BALF $2 \mathrm{~d}$ after infection. On day 8, however, adenosine degradation became very rapid and uric acid was produced, and adenosine that was added to the s-BALF was converted to uric acid in a stoichiometric manner within $60 \mathrm{~min}$ (Fig. 4). These results indicate that enzymes involved in conversion of adenosine to uric acid (i.e., ADA, purine nucleoside phosphorylase, and XO and XD) existed in BALF of virus-infected mice and that their activities were markedly enhanced on day 8 after viral infection. Furthermore, the purine salvage pathway, which uses hypoxanthine for production of ATP, does not play a significant role, at least in the bronchoalveolar space.

Identification of $\mathrm{O}_{2}^{-}$generation in $\mathrm{BALF}$. We measured $\mathrm{O}_{2}^{-}$ generation from XO in s-BALF. The results showed that generation of $\mathrm{O}_{2}^{-}$, which was determined by SOD-inhibitable cytochrome $c$ reduction, was detected in s-BALF on day 6 or day 8 , but not on days 0,2 , and 4 (Fig. 5). It is interesting that this $\mathrm{O}_{2}^{-}$generation was remarkably enhanced by addition of adenosine to the supernatant and was completely inhibited by ad-

Table III. Quantitation by HPLC of Catabolic Metabolites of Adenosine in Serum or s-BALF of Virus-infected Mice

\begin{tabular}{lccc}
\hline & \multicolumn{3}{c}{ Amount of metabolite $(\mu \mathrm{g} / \mathrm{ml})^{*}$} \\
\cline { 2 - 4 } Purine metabolites & Day 0 & Day 4 & Day 8 \\
\hline Serum & & & \\
$\quad$ Adenosine & $1.96 \pm 0.34$ & $1.76 \pm 0.19$ & $1.74 \pm 0.10$ \\
Inosine & $24.8 \pm 0.9$ & $42.3 \pm 1.3$ & $44.4 \pm 0.5$ \\
Hypoxanthine & $1.35 \pm 0.58$ & $3.66 \pm 0.20$ & $4.95 \pm 0.61$ \\
Xanthine & $2.31 \pm 0.29$ & $3.77 \pm 0.90$ & $7.23 \pm 0.93$ \\
Uric acid & $20.8 \pm 3.0$ & $50.9 \pm 3.1$ & $105.5 \pm 9.8$ \\
s-BALF & & & - \\
Adenosine & $-\ddagger$ & - & - \\
Inosine & $-\ddagger$ & $0.09 \pm 0.00$ & $0.82 \pm 0.15$ \\
Hypoxanthine & $0.03 \pm 0.01$ & - & - \\
Xanthine & $-\neq$ & - & $1.06 \pm 0.14$ \\
Uric acid & $0.22 \pm 0.04$ & $0.22 \pm 0.05$ & \\
& & &
\end{tabular}

* Values are shown as means $\pm \mathrm{SE}$ of three determinations.

${ }^{\ddagger}$ Undetectable (below $10 \mathrm{ng} / \mathrm{ml}$ ). See text for details. 

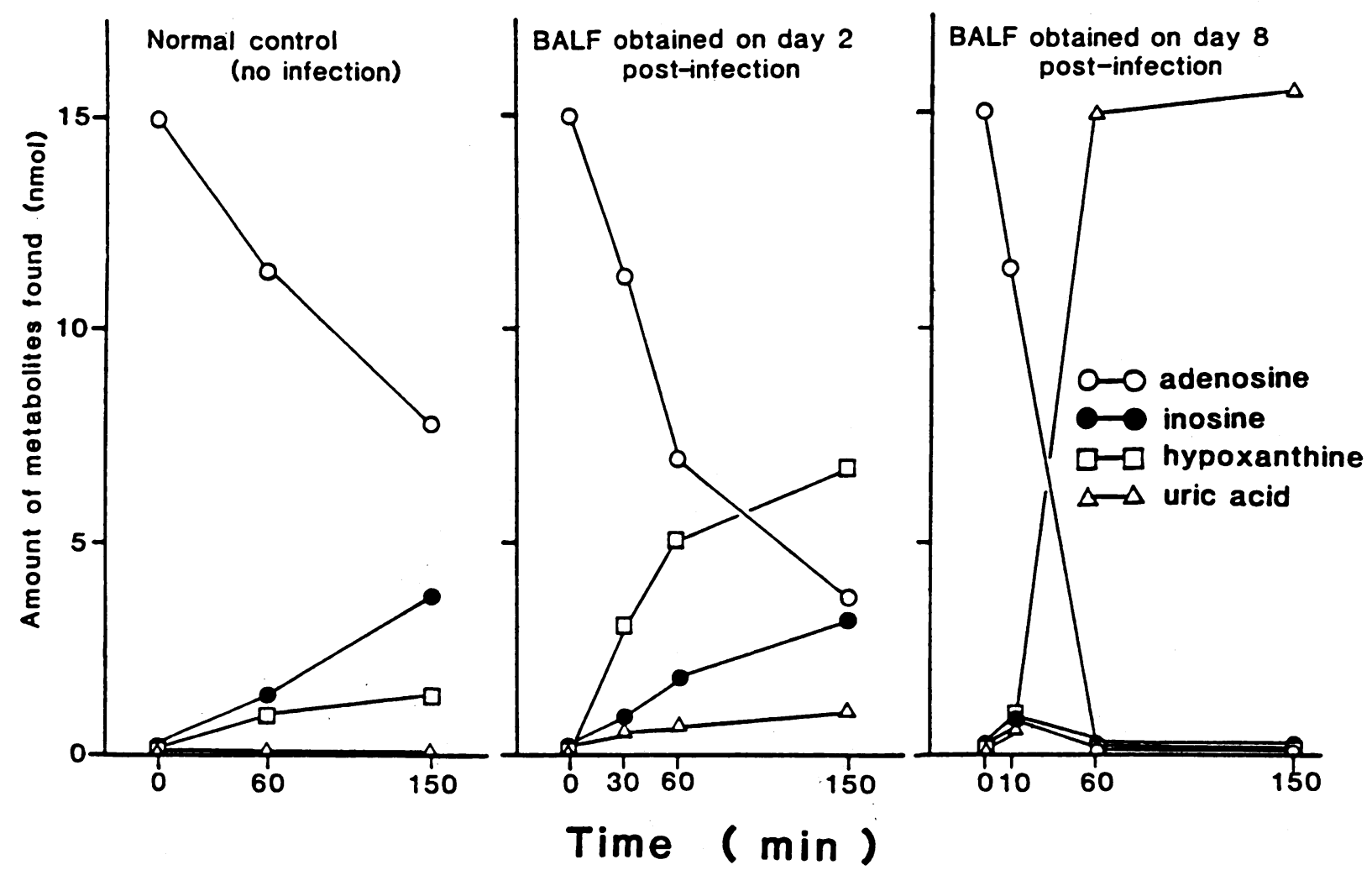

Figure 4. Catabolic profile of adenosine in s-BALF. Adenosine $(15.0 \mathrm{nmol})$ was added to $1 \mathrm{ml}$ of s-BALF, and after various incubation periods, the converted metabolites were quantitated by HPLC. See text for details.

dition of $45 \mu \mathrm{M}$ allopurinol, a specific inhibitor of $\mathrm{XO}$, which indicates that $\mathrm{O}_{2}^{-}$originated from $\mathrm{XO}$ in BALF.

Effect of allopurinol and SOD on the mortality of mice infected with influenza virus. If $\mathrm{O}_{2}^{-}$generated by $\mathrm{XO}$ is responsible for the pathogenesis of the viral infection, the inhibition of $\mathrm{XO}$ by allopurinol and removal of $\mathrm{O}_{2}^{-}$by the scavenger (SOD) would have some therapeutic effect on the infection. As shown in Fig. 6, $A$ and $B$, we found that use of both allopurinol and SOD reduced the lethal effect of influenza virus infection. In this experiment, we used the pyran-SOD, which possesses better pharmacokinetic properties (e.g., prolonged plasma half-life, tissue tropism, and biocompatibility) than native SOD (17). The result showed that this chemically modified SOD had a better therapeutic effect than native SOD (Fig. 6 $B)$, as was expected.

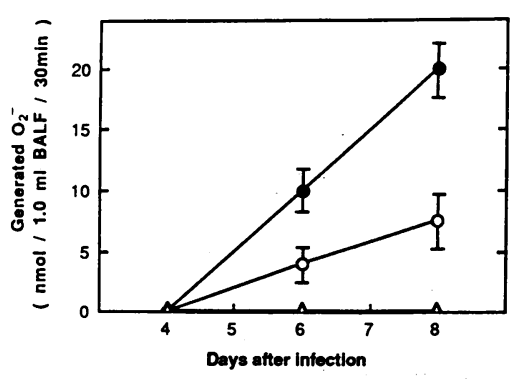

Figure $5 . \mathrm{O}_{2}^{-}$generation in s-BALF. Generated $\mathrm{O}_{2}^{-}$was determined spectroscopically in a mixture of $0.1 \mathrm{ml}$ each of s-BALF and $80 \mu \mathrm{M}$ ferricytochrome $c$ in a total volume of $1.0 \mathrm{ml}$ of PBS in the presence or absence of $20 \mu \mathrm{g}$ of SOD and/or $22.5 \mathrm{nmol}$

of adenosine. $\bullet, \mathrm{O}_{2}^{-}$generation with adenosine; $\mathrm{O}$, without adenosine. $\mathrm{O}_{2}^{-}$generation was inhibited completely by $45 \mu \mathrm{M}$ of allopurinol $(\Delta)$. Data are means $\pm \mathrm{SE}, n=3$.

\section{Discussion}

The pathogenic role of $\mathrm{O}_{2}^{-}$in influenza virus-infected mice was elucidated in this paper. We showed enhancement of both adenosine catabolism and $\mathrm{O}_{2}^{-}$generation by $\mathrm{XO}$ in mice that had a lethal infection with influenza virus. We also demonstrated a therapeutic effect of allopurinol (an XO inhibitor) and pyran-SOD (an $\mathrm{O}_{2}^{-}$scavenger). This is the first detailed report showing that $\mathrm{O}_{2}^{-}$generation by $\mathrm{XO}$ is one of the major pathogenic mechanisms of infection by influenza virus.

Among the enzymes involved in catabolism of purine (i.e., adenosine), ADA occupies the first key step. Increasing interests have been focused on this enzyme because a significant correlation between deficiency of ADA and the presence of severe combined immunodeficiency disease was noted (24). In addition, an important role in immune response, especially $\mathrm{T}$ cell activity, has been described for $\operatorname{ADA}(25,26)$. We recently reported diagnostic significance of ADA activity in the serum of patients with mycoplasma pneumonia (27), in which $\mathrm{T}$ cells appear to hinder proliferation of Mycoplasma $(28,29)$. Histological examination has revealed predominant infiltration of lymphocytes in the pneumonic area of the lung infected by influenza virus $(4,18)$, and Sullivan et al. reported that the $T$ cell-mediated immune responses play a crucial role in the pathogenesis of influenza virus infection in mice (2). Therefore, these results suggest that the pronounced elevation of ADA activity in serum and BALF of virus-infected mice reflects a hyperimmune reaction against virus replication in the lung.

Several investigators have reported that morbidity and 

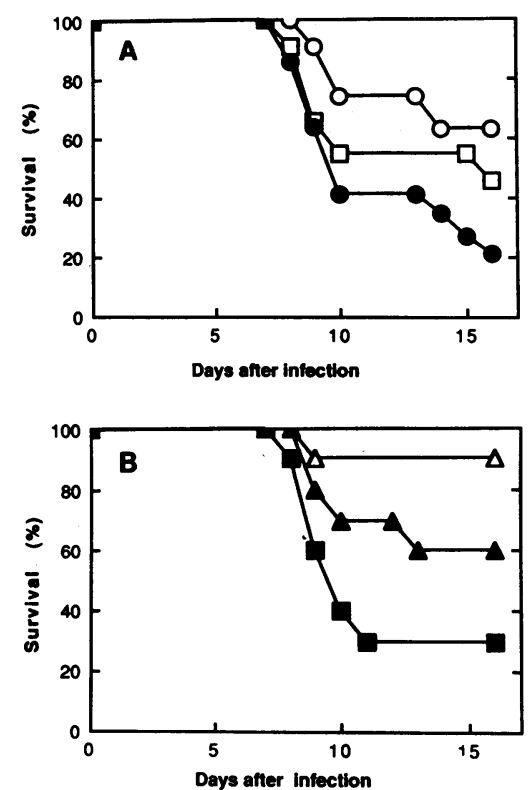

-10) received ste values for the difference between allopurinol-treated $(2 \mathrm{mg})$ and control mice and for the difference between pyran-SOD-treated (200 U) and control mice were 0.04 and 0.01 , respectively. A significant difference was not found between mice treated with $1 \mathrm{mg}$ of allopurinol or 1,000 U of SOD and control mice by Fisher's exact test.

mortality in the influenza virus-infected mice are mediated by an immunopathological mechanism (1-3). In these reports, treatment with antilymphocyte sera or cyclophosphamide to suppress lymphocyte function prolonged the survival rate of influenza virus-infected mice, which resulted from reduced lymphocyte infiltration of the lung $(1,30)$. Our present results indicated that an elevated level of ADA activity resulted in an elevated level of production of inosine, which is efficiently converted to hypoxanthine by purine nucleoside phosphorylase (Figs. 1 and 4). Hypoxanthine is the substrate for XO. Therefore, it is speculated that the immune response of the lymphocytes against viral infection results in production of $\mathrm{O}_{2}^{-}$ by XO.

In this experiment, we demonstrated the elevation of adenosine metabolites (i.e., inosine, hypoxanthine, xanthine, and uric acid) in s-BALF and serum of virus-infected mice. Although the levels of hypoxanthine and xanthine in s-BALF could not be detected by HPLC, perhaps due to rapid turnover by $\mathrm{XO}$, levels of other products (e.g., inosine and uric acid) increased markedly (Table III). $\mathrm{O}_{2}^{-}$generation by $\mathrm{XO}$ in the BALF was demonstrated on day 6 and to a greater degree on day 8 without any addition of adenosine (Fig. 5). Therefore, it is conceivable that increased production of hypoxanthine from adenosine, inosine, or other purine nucleosides (nucleotides) may occur in the lung of influenza virus-infected mice.

It became essential to validate the elevated level of XO activity in the lung, especially in BALF. Further, the conversion of XD to XO had to be confirmed in the virus-infected lung because $\mathrm{XO}$, not $\mathrm{XD}$, is responsible for the generation of $\mathrm{O}_{2}^{-}$. Previously, Waud and Rajagopalan (31) had investigated the molecular mechanism of XD $\rightarrow \mathrm{XO}$ conversion and found that two pathways of conversion occurred: Proteolytic cleavage and oxidation of the sulfhydryl group in the XD molecule.
We showed here also that XD $\rightarrow$ XO conversion in the lung tissue and BALF of influenza virus-infected mice occurred (Fig. 3). Although the conversion mechanism in our model remains unclear, we favor irreversible proteolytic conversion of XD to XO by the trypsin-like protease, because we have recently found that trypsin-like activity was induced to a large extent in the bronchoalveolar space of virus-infected mice (18). In addition, our preliminary experiment showed that treatment with soybean trypsin inhibitor (Kunitz type) improved the survival rate of influenza virus-infected mice (Akaike, T., H. Maeda, S. Ijiri, unpublished data).

It is well known that $\mathrm{O}_{2}^{-}$from $\mathrm{XO}$ has a pivotal role in ischemia and reperfusion injuries in some animal models (12). Johnson et al. previously demonstrated that intratracheal injection of $\mathrm{XO}$ and xanthine produced acute lung injury in a rat model, which could be reduced by $\mathrm{SOD}$, and that $\mathrm{O}_{2}^{-}$produced injury of the lung (32). Localization of XD in the tissue and its pathophysiological significance were also reported in detail by Jarasch et al. (33). They revealed that the location of XD is restricted to the mammary epithelial cells and the capillary endothelial cells in bovine and human tissues, and they speculated that a biological function of XD in the endothelial cells would be apparent when the enzyme (XD-form) is released into extracellular lumens (e.g., blood stream) and it may be converted to the harmful XO-form in an oxygen-rich environment by endothelial injury induced by microbes (33). Our present data suggest that the conversion of XD $\rightarrow \mathrm{XO}$ occurred most frequently in BALF obtained from bronchoalveolar spaces, which is an extracellular lumen and an oxygenrich environment. This finding seems to confirm the hypothesis by Jarasch et al., except that the conversion was not so apparent in the capillary lumen (i.e., plasma). Furthermore, the deleterious role of $\mathrm{XO}$ in various tissue injuries was reported in ARDS (13), hyperoxic and neutrophil-mediated lung injuries (14), ethanol intoxication in the liver (34), interferoninduced liver damage (35), and hematoporphyrin derivativemediated cutaneous photosensitization (36). Therefore, it is reasonable to conclude that both elevated $\mathrm{XO}$ activity in the lung and enhancement of purine catabolism (adenosine $\rightarrow$ hypoxanthine) would facilitate lung tissue injuries by the generation of $\mathrm{O}_{2}^{-}$, which must be then converted to more toxic oxygen metabolites (i.e., $\cdot \mathrm{OH})(15,16)$.

Several reports have shown the therapeutic effect of allopurinol in premature infants with idiopathic respiratory distress syndrome (37) and in ischemia-reperfusion injuries in animal models $(38,39)$. Two major pathways can account for this effect. One is the enhancement of hypoxanthine salvage (purine salvage pathway) for ATP synthesis, and the other is the inhibition of $\mathrm{XO}$, which generates $\mathrm{O}_{2}^{-}$by catalytic action. In our model, we demonstrated that adenosine added to BALF was quantitatively catabolized to uric acid (Fig. 4) and that there was simultaneous $\mathrm{O}_{2}^{-}$generation by XO (Fig. 5). Furthermore, in addition to allopurinol, pyran-SOD had a therapeutic effect on the survival rate of virus-infected mice (Fig. 6). The improvement of survival rate by allopurinol, therefore, seems to have resulted from the inhibition of $\mathrm{O}_{2}^{-}$generation by the action of XO.

In conclusion, this work clarified that the oxygen-free radical generated by $\mathrm{XO}$ is a pathologic principle in influenza virus infection in mice and that a therapeutic approach by elimination of the radical oxygen seems possible. 


\section{Acknowledgments}

We thank Ms. M. Fujii for typing, and Ms. Judith Gandy for editing, the manuscript.

A large part of this work was supported by grants-in-aid for Research from Monbusho (Ministry of Education, Science \& Culture), Japan.

\section{References}

1. Hurd, J., and R. B. Heath. 1975. Effect of cyclophosphamide on infections in mice caused by virulent and avirulent strains of influenza virus. Infect. Immun. 11:886-889.

2. Sullivan, J. L., R. E. Mayner, D. W. Barry, and F. A. Ennis. 1976. Influenza virus infection in nude mice. J. Infect. Dis. 133:91-94.

3. Shimomura, E., F. Suzuki, and N. Ishida. 1982. Characterization of cells infiltrating the lungs of $\mathrm{X}$-irradiated and nude mice after influenza virus infection. Microbiol. Immunol. 26:129-138.

4. Oda, T., T. Akaike, T. Hamamoto, F. Suzuki, T. Hirano, and H. Maeda. 1989. Oxygen radicals in influenza-induced pathogenesis and treatment with pyran polymer-conjugated SOD. Science (Wash. DC). 244:974-976.

5. Cochrane, C. G., R. Spragg, and S. D. Revak. 1983. Pathogenesis of the adult respiratory distress syndrome. Evidence of oxidant activity in bronchoalveolar lavage fluid. J. Clin. Invest. 71:754-761.

6. Tate, R. M., and J. E. Repine. 1983. Neutrophils and the adult respiratory distress syndrome. Am. Rev. Respir. Dis. 128:552-559.

7. Carp, H., and A. Janoff. 1978. Possible mechanisms of emphysema in smokers. In vitro suppression of serum elastase-inhibitory capacity by fresh cigarette smoke and its prevention by antioxidants. Am. Rev. Respir. Dis. 118:617-621.

8. Barry, B. E., and J. D. Crapo. 1985. Patterns of accumulation of platelets and neutrophils in rat lungs during exposure to $100 \%$ and $85 \%$ oxygen. Am. Rev. Respir. Dis. 132:548-555.

9. Blake, D. R., N. D. Hall, P. A. Bacon, P. A. Dieppe, B. Halliwell, and J. M. C. Gutteridge. 1983. Effect of a specific iron chelating agent on animal models of inflammation. Ann. Rheum. Dis. 42:89-93.

10. Sanfey, H., M. G. Sarr, G. B. Bulkley, and J. L. Cameron. 1986. Oxygen-derived free radicals and acute pancreatitis: a review. Acta Physiol. Scand. Suppl. 548:109-118.

11. McCord, J. M. 1985. Oxygen-derived free radicals in postischemic tissue injury. N. Engl. J. Med. 312:159-163.

12. Granger, D. N., M. E. Höllwarth, and D. A. Parks. 1986. Ischemia-reperfusion injury: role of oxygen-derived free radicals. Acta Physiol. Scand. Suppl. 548:47-63.

13. Grum, C. M., R. A. Ragsdale, L. H. Ketai, and R. H. Simon. 1987. Plasma xanthine oxidase activity in patients with adult respiratory distress syndrome. J. Crit. Care. 2:22-26.

14. Rodell, T. C., J. C. Cheronis, C. L. Ohnemus, D. J. Piermattei, and J. E. Repine. 1987. Xanthine oxidase mediates elastase-induced injury to isolated lungs and endothelium. J. Appl. Physiol. 63:21592163

15. Graf, E., J. R. Mahoney, R. G. Bryant, and J. W. Eaton. 1984. Iron-catalyzed hydroxyl radical formation. J. Biol. Chem. 259:36203624.

16. Halliwell, B., and J. M. C. Gutteridge. 1984. Oxygen toxicity, oxygen radicals, transition metals and disease. Biochem. J. 219:1-14.

17. Maeda, H., T. Oda, Y. Matsumura, and M. Kimura. 1988. Improvement of pharmacological properties of protein-drugs by tailoring with synthetic polymers. J. Bioactive Compatible Polymers. 3:27-43.

18. Akaike, T., A. Molla, M. Ando, S. Araki, and H. Maeda. 1989. Molecular mechanism of complex infection by bacteria and virus analyzed by a model using serratial protease and influenza virus in mice. $J$. Virol. 63:2252-2259.

19. Ginsberg, H. S., and F. L. Horsfall, Jr., 1952. Quantitative aspects of the multiplication of influenza A virus in the mouse lung. $J$. Exp. Med. 95:135-145.

20. Begleiter, A., R. I. Glazer, L. G. Israels, L. Pugh, and J. B. Johnston. 1987. Induction of DNA strand breaks in chronic lymphocytic leukemia following treatment with 2'-deoxycoformycin in vivo and in vitro. Cancer Res. 47:2498-2503.

21. Haining, J. L., and J. S. Legan. 1967. Fluorometric assay for xanthine oxidase. Anal. Biochem. 21:337-343.

22. Lowry, O. H., N. J. Rosebrough, A. L. Farr, and R. J. Randall. 1951. Protein measurement with Folin phenol reagent. J. Biol. Chem. 193:265-275.

23. Johnston, R. B., Jr., C. A. Godzik, and Z. A. Cohn. 1978. Increased superoxide anion production by immunologically activated and chemically elicited macrophages. J. Exp. Med. 148:115-127.

24. Giblett, E. R., J. E. Anderson, F. Cohen, B. Pollara, and H. J. Meuwissen. 1972. Adenosine-deaminase deficiency in two patients with severely impaired cellular immunity. Lancet. ii:1067-1069.

25. Ballent, J.-J., R. Insel, E. Merler, and F. S. Rosen. 1976. Inhibition of maturation of human precursor lymphocytes by coformycin, an inhibitor of the enzyme adenosine deaminase. J. Exp. Med. 143:1271-1276.

26. Sullivan, J. L., W. R. A. Osborne, and R. J. Wedgwood. 1977. Adenosine deaminase activity in lymphocytes. Br. J. Haematol. 37:157-158.

27. Nishikawa, H., M. Suga, M. Ando, F. Tanaka, and S. Araki. 1988. Serum adenosine deaminase activity with Mycoplasma pneumoniae. Chest. 94:1315.

28. Denny, F. W., D. Taylor-Robinson, and A. C. Allison. 1972. The role of thymus-dependent immunity in Mycoplasma pulmonis infections of mice. J. Med. Microbiol. 5:327-336.

29. Biberfeld, G., P. Biberfeld, and G. Sterner. 1974. Cell-mediated immune response following Mycoplasma pneumoniae infection in man. I. Lymphocyte stimulation. Clin. Exp. Immunol. 17:29-41.

30. Suzuki, F., J. Ohya, and N. Ishida. 1974. Effect of antilymphocyte serum on influenza virus infection in mice. Proc. Soc. Exp. Biol. Med. 146:78-84.

31. Waud, W. R., and K. V. Rajagopalan. 1976. The mechanism of conversion of rat liver xanthine dehydrogenase from an $\mathrm{NAD}^{+}$-dependent form (type $\mathrm{D}$ ) to an $\mathrm{O}_{2}$-dependent form (type $\mathrm{O}$ ). Arch. Biochem. Biophys. 172:365-379.

32. Johnson, K. J., J. C. Fantone III, J. Kaplan, and P. A. Ward. 1981. In vivo damage of rat lungs by oxygen metabolites. J. Clin. Invest. 67:983-993.

33. Jarasch, E.-D., G. Bruder, and H. W. Heid. 1986. Significance of xanthine oxidase in capillary endothelial cells. Acta Physiol. Scand. Suppl. 548:39-46.

34. Sultatos, L. G. 1988. Effects of acute ethanol administration on the hepatic xanthine dehydrogenase/oxidase system in the rat. $J$. Pharmacol. Exp. Ther. 246:946-949.

35. Ghezzi, P., M. Bianchi, L. Gianera, S. Landolfo, and M. Salmona. 1985. Role of reactive oxygen intermediates in the interferonmediated depression of hepatic drug metabolism and protective effect of $N$-acetylcyteine in mice. Cancer Res. 45:3444-3447.

36. Athar, M., C. A. Elmets, D. R. Bickers, and H. Mukhtar. 1989. A novel mechanism for the generation of superoxide anions in hematoporphyrin derivative-mediated cutaneous photosensitization. Activation of the xanthine oxidase pathway. J. Clin. Invest. 83:1137-1143.

37. Boda, D., I. Németh, P. Hencz, and K. Dénes. 1984. Effect of allopurinol treatment in premature infants with idiopathic respiratory distress syndrome. Dev. Pharmacol. Ther. 7:357-367.

38. Manning, A. S., D. J. Coltart, and D. J. Hearse. 1984. Ischemia and reperfusion-induced arrhythmias in the rat. Effect of xanthine oxidase inhibition with allopurinol. Circ. Res. 55:545-548.

39. Lasley, R. D., S. W. Ely, R. M. Berne, and R. M. Mentzer, Jr. 1988. Allopurinol enhanced adenine nucleotide repletion after myocardial ischemia in the isolated rat heart. J. Clin. Invest. 81:16-20. 